\title{
KONVERGENSI EKOLINGUISTIK DAN FIQH AL BI'AH DALAM PELESTARIAN LINGKUNGAN
}

\author{
Akmaluddin \\ Universitas Islam Negeri Mataram \\ Corresponding Author: akmal@uinmataram.ac.id
}

Article History

Submitted: 28 Sept 2020; Revised: 27 Dec 2020; Accepted:31 Dec 2020

DOI: 10.20414 / tsaqafah.v19i2.2623

\begin{abstract}
This article is motivated by several realities, namely: (1) There is a strong symptom of the uprooting of local wisdom values among the younger generation. (2) There are symptoms of incompatibility between human relations and the environment that influence each other. (3) The liveliness of regional languages which contains local wisdom values is due to the influence of the domination of foreign languages. This reality needs to be examined from an ecolinguistic perspective and fiqh al-biah in an effort to conserve the environment. On this basis, this paper aims to explore the intersection between two interdisciplinary studies, namely ecolinguistics and fiqh al-bi'ah. The approach used in this research is descriptive comparative approach. This approach is used with the aim of providing a comparative picture or description of a situation objectively viewed from different points of view. In this research, the connected object is the environmental reality in terms of interdisciplinary ecolinguistics and fiqh al-bi'ah. Sources of data in this study are linguistic realities related to environmental problems. The results of this study indicate that there are several forms of language that have the potential to become extinct due to changes in interaction patterns with the environment. In addition, undirected patterns of human interaction also result in environmental damage. In line with the results of studies conducted by many researchers, this article concludes that the rules of figh al-bi'ah and ecolinguistic concepts need to be used as a basis for interacting with the environment.
\end{abstract}

Keywords: convergence, ecolinguistics, fiqh al-bi'ah

Abstrak : Artikel ini dilatarbelakangi oleh beberapa realitas yaitu: (1) Adanya gejala yang kuat terhadap ketercerabutan nilai-nilai kearifan lokal (local wisdom) di kalangan generasi muda. (2) Adanya gejala ketidakserasian hubungan manusia dengan lingkungan yang saling memengaruhi. (3) Keterancaman hidup bahasa-bahasa daerah yang memuat nilai-nilai kearifan 
lokal karena pengaruh dominasi bahasa asing. Realitas ini perlu ditelaah dari perspektif ekolinguistik dan fiqh al-bi'ah dalam upaya pelestarian lingkungan. Atas dasar inilah tulisan ini bertujuan mengeksplorasi titik temu antara dua kajian interdisipliner yaitu ekolinguistik dan figh al-bi'ah. Pendekatan yang digunakan dalam penelitian ini adalah pendekatan komparatif deskriptif. Pendekatan ini digunakan dengan tujuan untuk memberikan gambaran atau deskripsi komparatif tentang suatu keadaan secara objektif yang dipandang dari sudut pandang yang berbeda. Dalam penelitian ini objek yang dikoneksikan adalah realitas lingkungan yang ditinjau dari interdisipliner ilmu ekolinguistik dan figh al-bi'ah. Sumber data dalam penelitian ini adalah realita kebahasaan yang berkaitan dengan permasalahan lingkungan. Hasil penelitian ini menunjukkan bahwa terdapat beberapa bentuk bahasa yang berpotensi punah akibat perubahan pola interaksi dengan lingkungan. Selain itu, pola interaksi manusia yang tidak terarah juga mengakibatkan terjadinya kerusakan lingkungan. Selaras dengan hasil-hasil kajian yang telah dilakukan banyak peneliti, artikel ini menyimpulkan bahwa kaidah-kaidah fiqh al$b i$ 'ah dan konsep-konsep ekolinguistik perlu dijadikan dasar pijakan dalam berinteraksi dengan lingkungan.

Kata kunci: konvergensi, ekolinguistik, fiqh al-bi'ah

\section{A. Pendahuluan}

Salah satu wujud perkembangan ilmu pengetahuan adalah munculnya beragam kajian interdisipliner sehingga semakin membuka peluang penemuan-penemuan baru dalam berbagai bidang kajian keilmuan. Contoh kajian interdisipliner yang ada dan merupakan bagian dari sekian banyak kajian interdisipliner adalah ekolinguistik dan fiqh al-bi'ah. Kedua bidang ilmu interdisipliner ini memiliki kesamaan objek kajian yang dikaitkan dengan perspektif yang berbeda. Ekolinguistik membedah gejala lingkungan baik lingkungan alam maupun lingkungan sosial yang dapat mempengaruhi bahasa sedangkan fiqh al-bi'ah melihat lingkungan alam dalam perspektif kaidah fiqhiyah. Artikel atau hasil penelitian ilmiah lainnya yang mencoba menemukan titik konvergensi antara kedua kajian interdisipliner ini tidaklah banyak dilakukan oleh para ahli sehingga menurut penulis sangat relevan untuk diangkat menjadi topik dalam dalam penelitian ini.

Kaitan antara lingkungan dengan bahasa menjadi topik yang layak diangkat dalam tulisan ilmiah disebabkan oleh beberapa alasan. Pertama, adanya gejala yang kuat terhadap ketercerabutan nilai-nilai kearifan lokal (local wisdom) di kalangan generasi muda karena pudarnya fungsi bahasa dan budaya daerah seiring dengan berkembangnya pola kehidupan masyarakat. Kedua, adanya gejala ketidakserasian hubungan manusia dengan lingkungan baik lingkungan alam maupun lingkungan sosial yang saling mempengaruhi. Ketiga, keterancaman hidup bahasa-bahasa daerah yang memuat nilai-nilai kearifan lokal termasuk bahasa Indonesia karena pengaruh 
dominasi bahasa asing. ${ }^{1}$ Keempat, berdasarkan hasil penelitian yang dilakukan oleh Mardiati (2016) tentang penyusutan leksikon bahasa daerah yang disebabkan oleh hilangnya kegiatan-kegiatan sosial, budaya, ekonomi, dan pertanian tertentu. ${ }^{2}$ Alasan-alasan ini membawa kita pada satu kesimpulan bahwa lingkungan, memiliki pengaruh besar terhadap kelangsungan dan kebertahanan bahasa yang mengandung nilai-nilai kearifan lokal yang patut dilestarikan.

Pelestarian lingkungan dalam perspektif agama pun tidak luput yang ditandai dengan banyaknya ayat Alquran maupun hadis Nabi yang berbentuk perintah secara langsung, peringatan, maupun kisah yang berbicara masalah pelestarian lingkungan. Selain hal ini adalah bukti Islam sebagai agama yang komprehensif mengatur seluruh sendi kehidupan, perhatian agama terhadap pelestarian lingkungan ini karena sangat berkaitan dengan perjalanan hidup manusia secara umum. Perhatian menegaskan bahwa Islam sebagai rahmatan lil alamin bukanlah sekadar moto apalagi sekadar tulisan hias pada dinding, melainkan bentuk penegasan bahwa rahmatan lil alamin adalah tujuan Islam itu sendiri. ${ }^{3}$

Pelestarian dan penyelamatan lingkungan menjadi isu yang selalu menarik dikupas dalam berbagai forum diskusi pun menjadi topik yang tetap relevan diangkat dalam berbagai tulisan ilmiah. Hal ini disebabkan penyelamatan lingkungan memiliki efek terhadap berbagai sendi kehidupan. Namun realitas ini seolah hanya ramai pada tataran diskusi sementara berbagai tindakan yang mengarah pada perusakan keseimbangan ekosistem terus terjadi. Jika hal ini terus diabaikan, dampak yang ditimbulkan tentu sangat berbahaya bagi kelangsungan hidup manusia. Dengan demikian, pelestarian lingkungan harus menjadi perhatian pemerintah, masyarakat, tokoh agama, pendidik, dan semua pihak dengan beragam kapasitas dan kemampuan masing-masing.

Busriyanti (2016) menyebutkan bahwa masalah lingkungan hidup merupakan masalah global yang semakin disadari sebagai masalah yang kompleks dan serius yang dihadapi oleh umat manusia di seluruh dunia. ${ }^{4}$ Kompleksitasnya masalah lingkungan ini disebabkan oleh ulah tangan manusia dalam upaya memenuhi kebutuhan hidupnya. Interaksi manusia dengan lingkungan ini terkadang tidak ada keserasian sehingga pada akhirnya akan membahayakan kelangsungan hidup manusia itu sendiri. Berbagai macam kasus kerusakan lingkungan di laut, darat, dan udara akibat perilaku manusia yang tidak bertanggung jawab ini oleh Keraf (2010) disebut sebagai

1 Aron Meko Mbete, "Pembelajaran Bahasa Berbasis Lingkungan: Perspektif Ekolinguistik (Makalah Bahan Kuliah Umum bagi Karyasiswa Program Magister Pendidikan Bahasa Indonesia Program Pascasarjana Universitas Mataram, 2013), tidak diterbitkan.

2 Baiq Tutik Mardiati, Penyusutan Leksikon Bidang Ekonomi pada Masyarakat Tutur Bahasa Sasak dan Implikasinya terhadap Pembelajaran Bahasa Indonesia Tingkat SD di Desa Barabali Kecamatan Batu Kliang (Mataram: Tesis Universitas Mataram, 2016)

3 Busriyanti. Islam dan Lingkungan Hidup Studi terhadap Fiqh al-Bi'ah sebagai Solusi Pelestarian Ekosistem dalam Perspektif Maqashid al-Syari’ah. Jurnal Fenomena: 259-280. IAIN Jember, 2016.

4 Ibid 
ketidakpedulian yang hanya mementingkan diri sendiri. ${ }^{5} \mathrm{Hal}$ ini sering tidak disadari sehingga diperlukan adanya sosialisasi yang masif dan tindakan konkret yang dapat dilakukan oleh semua pihak.

Penelitian ini ingin menarik suatu titik temu antara kajian ekolinguistik dengan figh al-bi'ah sebagai perspektif dalam upaya pelestarian lingkungan. Adapun kaitan yang dapat dirumuskan sebagai titik temu antara kedua kajian interdisipliner ini adalah bahwa dalam kajian ekolinguistik diperlukan adanya perilaku-perilaku kebahasaan yang dapat menjadi alternatif pelestarian lingkungan. Hal ini dimungkinkan karena dalam tradisi lingkungan sosial terkandung nilai-nilai kearifan lokal disertai dengan unsur-unsur kebahasaan yang luhur dan semestinya dilestarikan. Dengan demikian, hilangnya suatu tradisi, budaya, kearifan lokal, bahkan keseimbangan ekosistem tertentu dapat berpengaruh pada menyusutnya beberapa unsur kebahasaan. Pada sisi yang lain, secara simultan kaidah-kaidah fiqhiyah mengajarkan kepada manusia untuk selalu menjaga kelestarian lingkungan sebagai bentuk penegasan Islam hadir sebagai rahmatan lil alamin. Dalil-dalil Alquran dan hadis yang berkatian dengan perintah menjaga kelestarian lingkungan perlu dieksplorasi lebih dalam sehingga muncul kesadaran yang kuat untuk selalu menjaga lingkungan. Dengan demikian, akan ditemukan satu titik konvergensi antara kajian ekolinguistik dan fiqh al-bi'ah yaitu tanggung jawab pelestarian lingkungan.

\section{B. Kerangka Teori}

\section{Penelitian Relevan}

a. Penyusutan Leksikon Bidang Ekonomi pada Masyarakat Tutur Bahasa Sasak dan Implikasinya terhadap Pembelajaran Bahasa Indonesia Tingkat SD di Barabali Kecamatan Batukliang (Baiq Tutik Mardiati, 2016).

Penelitian yang mengangkat kajian tentang kaitan antara kasus kebahasaan dengan masalah lingkungan pernah dilakukan oleh Mardiati (2016). Mardiati (2016) melakukan penelitian berbasis realitas bahwa sebuah budaya yang bergeser karena adanya budaya baru secara otomatis menyebabkan hilangnya beberapa kosakata yang terkait dengan budaya tersebut. Artinya, lingkungan sangat berpengaruh terhadap eksistensi unsur-unsur kebahasaan. Penelitian yang telah dilakukan Mardiati (2016) menghasilkan kesimpulan bahwa terdapat penyusutan leksikon lingkungan yang disebabkan oleh dua faktor yaitu faktor penutur dan faktor perubahan sosial budaya yang terjadi di masyarakat. Lebih lanjut hasil penelitian Mardiati (2016) merincikan bahwa penyusutan leksikon dalam bidang pertanian sebanyak 17\% dari 38 leksikon yang diujikan. Sedangkan penyusutan leksikon dalam bidang perkebunan sebanyak 17,5\% dari 50 kata yang diujikan. Penyusutan leksikon ini terjadi karena perubahan budaya yang terjadi di masyarakat. Sebagai contoh faktual dalam penelitian tersebut adalah leksikon tenggale 'alat pembajak sawah tradisional' yang saat ini jarang dijumpai alatnya sehingga leksikonnya pun jarang didengar oleh masyarakat. Penyusutan

5 A. Sony Keraf, Etika Lingkungan Hidup (Jakarta: PT Kompas Media Nusantara, 2010) hlm. 5. 
leksikon ini disebabkan oleh perkembangan teknologi yang mengganti tenggale dengan traktor. Permasalahan ini tentu tidak berhenti pada sekadar peyusutan kata namun tentu ada budaya yang bergeser.

b. Islam dan Lingkungan Hidup Studi terhadap Fiqh Al-Bi'ah sebagai Solusi Pelestarian Ekosistem dalam Perspektif Maqashid Al-Syari'ah (Busriyanti, 2016).

Penelitian lain yang mengangkat topik pelestarian lingkungan dalam perspektif fiqh al-bi'ah adalah penelitian yang dilakukan oleh Busriyanti (2016). Berbeda dengan penelitian Mardiati yang mengaitkan kasus kebahasaan dengan lingkungan, Busriyanti melakukan penelitian tentang pelestarian lingkungan dengan perspektif fiqh al-bi'ah. Busriyanti berpijak pada realaitas bahwa kerusakan lingkungan yang terjadi di Indonesia pada khususnya dan di berbagai belahan dunia secara umum merupakan masalah serius yang dapat membahayakan kehidupan manusia. Dalam situasi ini, terminologi pengeloaan lingkungan lebih didominasi oleh ahli-ahli dari barat. Hal ini menyebabkan seolah Islam yang hadir sebagai rahmatan lil alamin tidak menaruh perhatian terhadap permasalahan lingkungan. Atas dasar inilah perspektif fiqh al-bi'ah menjadi kajian interdisipliner yang patut dikembangkan.

Penelitian yang dilakukan Busriyanti menyimpulkan bahwa wacana pemeliharaan lingkungan sebagai bagian dari maqashid al-syariah adalah suatu hal yang penting untuk dijadikan sebagai bahan kajian dalam merespons dinamika kehidupan manusia di era modern. Dengan demikian, keberadaan syari'at Islam dapat memberikan kontribusi pemikiran dalam menghadapi tantangan kehidupan masa kini.

c. "Pembelajaran Bahasa Berbasis Lingkungan: Perspektif Ekolinguistik (Aron Meko Mbete, 2013)

Selain hasil penelitian di atas, Mbete (2013) juga melakukan penelitian tentang lingkungan dengan perspektif ekolinguistik. Dalam penelitiannya, Mbete menjelaskan bahwa ekolinguistik menjadi penting karena dua alasan: Pertama, banyak generasi muda sekarang ini khususnya yang tinggal di daerah perkotaan tidak lagi mengenal tumbuhan yang ada di daerahnya dalam wujud bahasa daerah mereka. Pengetahuan tentang keragaman hayati dan teknologi tradisional tertentu yang ramah lingkungan sangat penting bagi generasi saat ini. Kedua, keanekaragaman hayati yang ada di lingkungan sekitar pada hakikatnya merupakan sumber kekayaan bahasa baik pada bidang leksikon, semantik maupun gramatik. Semua ini akan memperkaya kategori nomina sekaligus memperkaya medan makna referensial ekstralingual bahasa tersebut. ${ }^{6} \mathrm{Hal}$ ini mengisyaratkan bahwa sumber belajar sebetulnya sungguh banyak dan dapat berasal dari lingkungan sekitar sehingga pelestarian lingkungan menjadi hal yang harus dilakukan. 
Lebih lanjut, Mbete (2013) menyebutkan bahwa keanekaragaman hayati di lingkungan sekitar tidak hanya memperkaya leksikon beserta medan makna yang dimilikinya. Namun lebih dari itu, pada sisi yang lain keanekaragaman hayati telah menjadi inspirasi bagi guyub tutur untuk membuat tamsilan yang penuh motivasi dan layak diajarkan dari generasi ke generasi. Semisal peribahasa Indonesia popular yang menyebutkan "ibarat padi yang semakin berisi semakin merunduk" yang mengandung makna mendalam bahwa seseorang tidak layak untuk menyombongkan diri dengan ilmu pengetahuan yang dimilikinya. Atau dalam peribahasa Sasak yang mengandung kearifan lokal dengan terinspirasi keanekaragaman hayati misalnya "bejunjung sik tereng odak" yang mengandung makna janganlah menjanjikan seseorang sesuatu yang tidak bisa kita lakukan. Kedua peribahasa ini terinspirasi lingkungan alam yang memiliki nilai-nilai kearifan lokal yang patut diajarkan dari generasi satu ke generasi lainnya. Selain mengandung kearifan lokal, peribahasa tersebut tentu memperkaya unsur kebahasaan baik bahasa Indonesia maupun bahasa daerah. Dapat dibayangkan jika lingkungan tidak dapat dilestarikan tentu salah satu sumber kekayaan bahasa akan hilang.

Pada tataran yang lebih kompleks, lingkungan dapat pula menjadi salah satu alternatif dalam membuat variasi bahan pembelajaran sebagaimana yang disarankan Mbete (2013). ${ }^{7}$ Mbete menjelaskan bahwa penulisan bahan ajar yang lebih kreatif khususnya penulisan bahan bacaan yang dapat dimanfaatkan dalam meningkatkan keterampilan membaca dan menulis para peserta didik dapat dilakukan dengan memanfaatkan pendekatan ekolinguistik.

\section{Teori Relevan}

\section{a. Lingkungan Hidup dalam Perspektif Ekolinguistik dan Figh al-Bi'ah}

Uraian pendahuluan di atas telah menjelaskan bahwa ekolinguistik merupakan satu kajian linguistik yang melihat hubungan bahasa dengan masalah ekologi dan lingkungan. Bidang ilmu interdisipliner yang mengelaborasi ekologi dan linguistik ini telah dimulai sejak tahun 1970-an ketika Einar Haugen (1972) mengemukakan paradigma 'ekologi bahasa'. ${ }^{8}$ Lebih lanjut Haugen memberkan definisi bahwa ekologi bahasa adalah telaah tentang interaksi bahasa dan lingkungannya. Istilah ekologi bahasa ini terus mengalami perkembangan terutama dua dekade setelah dicetuskan oleh Haugen yaitu munculnya istilah ekolinguistik yang dipelopori oleh Halliday (1990) pada konferensi AILA. Halliday merincikan beberapa unsur dalam sistem bahasa yang dianggap ekologis dan tidak ekologis. Halliday berpandangan bahwa sistem bahasa memiliki pengaruh terhadap perilaku penggunanya dalam mengelola lingkungan. Secara gamblang Halliday (1990) dalam tulisannya yang berjudul 'New Ways of Meaning' mejelaskan bahwa bahasa dan lingkungan merupakan dua entitas

7 Aron Meko Mbete, "Pembelajaran Bahasa Berbasis Lingkungan: Perspektif Ekolinguistik (Makalah Bahan Kuliah Umum bagi Karyasiswa Program Magister Pendidikan Bahasa Indonesia Program Pascasarjana Universitas Mataram, 2013), tidak diterbitkan.

8 Agus Subianto, Ekolinguistik: Model Analisis dan Penerapannya (Semarang: Fakultas Ilmu Budaya Universitas Diponegoro) 
yang saling mempengaruhi. ${ }^{9}$ Perlu ditekankan kembali bahwa lingkungan dalam pembahasan ini dapat berupa lingkungan alam maupun lingkungan sosial yang di dalamnya terdapat hal yang tidak dapat dipisahkan yakni budaya.

Hubungan bahasa dan budaya yang merupakan satu hal yang eksistensinya dalam lingkungan tidak dapat dipungkiri telah banyak disinggung oleh para pakar. Para pakar antropologi misalnya berpendapat bahwa mengkaji suatu budaya akan dapat dilakukan dengan mengkaji bahasa pada suatu masyarakat. Hal ini didasarkan pada realitas bahwa bahasa dalam suatu bangsa merupakan bagian dari kebudayaan bangsa tersebut. Demikian pula dengan pakar linguistik yang berpandangan bahwa tidak mungkin mengkaji bahasa suatu bangsa tanpa mengkaji budaya bangsa tersebut. Hal ini disebabkan karena semantik sebagai subbidang dalam kajian bahasa mencakup kebudayaan penutur bahasa tersebut. Dengan demikian, antropolog berpandangan bahwa bahasa merupakan bagian dari kebudayaan sementara linguis berpandangan bahwa budaya merupakan salah satu dimensi dalam kajian bahasa. ${ }^{10}$ Simpulan dari dua pandangan ini adalah bahasa dan lingkungan merupakan dua entitas yang tidak dapat dipisahkan karena adanya sifat mempengaruhi. Dalam praktiknya, perubahan bentuk bahasa baik dalam bidang kosa kata maupun struktur kalimat tidak dapat dilepaskan dari perubahan lingkungan baik alam maupun sosial yang terjadi di masyarakat.

Lingkungan baik alam maupun sosial memiliki pengaruh terhadap keberlangsungan bahasa dan kearifan lokal pada suatu tempat. Kaitan lingkungan dengan bahasa ini dapat dilihat dari perspektif ekolinguistik. Ekolinguistik membedah gejala lingkungan yang dapat mempengaruhi bahasa.

Dalam perspektif kajian keagamaan, pelestarian lingkungan dapat dikaji dengan pendekatan figh al-bi'ah. Figh al-bi'ah dapat menjadi pedoman dalam berinteraksi dan mengelola lingkungan berlandaskan ajaran religi dan sebagai solusi alternatif dalam pengelolaan lingkungan. Sebagai agama yang rahmatan lil 'alamin Islam juga menitikberatkan ajarannya pada pengelolaan dan pelestarian lingkungan sebab masalah lingkungan adalah masalah kelangsungan hidup (manusia dan alam). Melestarikan lingkungan artinya ada upaya untuk menjamin kelangsungan hidup manusia, hewan, tumbuhan dan segala yang ada di alam sekitarnya. Sebaliknya, merusak lingkungan dalam bentuk apapun berarti membuat ancaman bagi keberlangsungan hidup manusia, alam dan segala isinya. Oleh karena itu, paradigma berpikir kita tentang fiqih perlu mendapat pencerahan sehingga tidak lagi berasumsi sempit bahwa fiqih hanya mengurus masalah-masalah ibadah. Namun fiqih juga mengatur berbagai realitas yang terjadi seiring dengan perkembangan zaman.

Islam hadir di muka bumi ini dengan misi rahmatan lil 'alamin sehingga ajarannya begitu kompleks dalam setiap sendi kehidupan. Islam bukanlah tuntunan ibadah semata, namun lebih dari itu Islam adalah pendidikan, ekonomi, politik, sosial,

9 ibid

10 Abdul Chaer, Psikolingistik Kajian Teoritik (Jakarta: PT Rineka Cipta, 2003) hlm. 62. 
budaya, hingga lingkungan. Kompleksitas ajaran Islam ini menjadi pertanda bahwa Islam sangat memperhatikan seluruh kebutuhan hidup manusia. Beberapa sendi kehidupan tersebut layak dan masih relevan untuk terus dikaji sehingga internalisasi ajaran-ajaran Islam sebagai agama rahmatan lil 'alamin bisa dilakukan dalam setiap sendi kehidupan.

\section{b. Konsep Maslahah dan Maqashid al-Syari'ah}

Fiqh lingkungan yang dirumuskan oleh para intelektual muslim mencerminkan dinamika fiqh terkait dengan adanya perubahan konteks dan situasi yang terjadi pada masa sekarang ini. Perubahan zaman yang terus berlangsung dan massif ini menuntut para ahli fiqh untuk membuat kajian-kajian fiqh kontemporer. Terkait dengan fiqh al-bi'ah terdapat dua konsep yang digunakan untuk membangun fiqh lingkungan yakni mashlahah dan maqashid asy-syari'ah. Kedua konsep ini sangat berkaitan karena konsep mashlahah merupakan unsur penting untuk merawat dan menjaga maqasid asy-syariah. Konsep mashlahah dan maqasid asy-syariah ini merupakan konsep pemeliharaan atau perlindungan total terhadap lima kebutuhan primer (alushul al-khamsah) yang meliputi: (1) perlindungan terhadap agama (hifzh al-din), (2) perlindungan jiwa (hifzh al-nafs), (3) perlindungan akal (hifzh al-'aql), (4) perlindungan keturunan (hifzh al-nasl), dan (5) perlindungan harta benda (hifzh al-mal).

Dalam hal pelestarian lingkungan, Yusuf Qardhawi bahkan menegaskan penerapan hukuman sanksi berupa kurungan (at-ta'zir) bagi pelaku perusakan lingkungan hidup yang ditentukan oleh pemerintah (waliyy al-amr). Berdasarkan perubahan pola interaksi masyarakat terhadap lingkungan yang cenderung tidak memperhatikan pelestarian ini, telah menimbulkan efek negatif terhadap keberlangsungan hidup bahasa lokal. Selain itu, interaksi dengan lingkungan yang tidak terkendali sangat berpotensi membahayakan kehidupan manusia. Adapun kaitan yang dapat dirumuskan sebagai titik temu antara kedua kajian interdisipliner ini adalah bahwa dalam kajian ekolinguistik diperlukan adanya perilaku-perilaku kebahasaan yang dapat menjadi alternatif pelestarian lingkungan. Hal ini dimungkinkan karena dalam tradisi lingkungan sosial terkandung nilai-nilai kearifan lokal disertai dengan unsur-unsur kebahasaan yang luhur dan semestinya dilestarikan. Dengan demikian, hilangnya suatu tradisi, budaya, kearifan lokal, bahkan keseimbangan ekosistem tertentu dapat berpengaruh pada menyusutnya beberapa unsur kebahasaan. Pada sisi yang lain, secara simultan kaidah-kaidah fiqhiyah mengajarkan kepada manusia untuk selalu menjaga kelestarian lingkungan sebagai bentuk penegasan Islam hadir sebagai rahmatan lil alamin. Dalil-dalil Alquran dan hadis yang berkatian dengan perintah menjaga kelestarian lingkungan perlu dieksplorasi lebih dalam sehingga muncul kesadaran yang kuat untuk selalu menjaga lingkungan. Dengan demikian, akan ditemukan satu titik konvergensi antara kajian ekolinguistik dan figh al-bi'ah yaitu tanggung jawab pelestarian lingkungan. 


\section{Metode Penelitian}

\section{Pendekatan Penelitian}

Pendekatan penelitian yang digunakan adalah pendekatan kualitatif deskriptif. Penentuan pendekatan ini didasarkan pada tujuan penelitian ini yaitu memberikan gambaran atau deskripsi tentang adanya titik temu atau konvergensi antara ekolinguistik dan fiqh al-bi'ah dalam pelestarian lingkungan secara objektif. Sumber data dalam penelitian ini adalah realita kasus kebahasaan di lapangan yang dipengaruhi oleh pola interaksi masyarakat dengan lingkungan. Artinya, pola interaksi masyarakat dengan lingkungan yang dapat memengaruhi berbagai unsur kebahasaan. Selain itu, perubahan pola interaksi dengan lingkungan ini telah menyebabkan kerusakan, ketidakseimbangan ekosistem yang berpotensi membahayakan kehidupan manusia.

\section{Sampel Penelitian}

Penentuan sampel dalam penelitian ini menggunakan teknik purposive sampling. Pengambilan sampelnya dilakukan dengan menentukan sendiri setiap objek yang dipilih sebagai sampel berdasarkan observasi dan dokumentasi yang dilakukan peneliti. Adapun objek penelitian yang dimaksud adalah beberapa kosakata bahasa daerah yang berpotensi punah karena perubahan pola interaksi masyarakat dengan lingkungan baik lingkungan sosial, budaya, maupun alam.

\section{Pengumpulan Data}

Data dalam penelitian ini dikumpulkan dengan menggunakan metode observasi dan dokumentasi. Observasi dilakukan pada unsur-unsur kebahasaan yang berpotensi punah akobat perubahan pola interaksi masyarakat dengan lingkungan. Adapun dokumentasi dilakukan pada unsur-unsur kebahasaan yang telah diobservasi. Setelah semua data yang direncanakan terkumpul, peneliti melakukan jejak audit. Arikunto (2013: 26) menjelaskan bahwa jejak audit berarti peneliti melakukan penelusuran dengan maksud memeriksa kembali data yang telah diperoleh.

\section{Analisis Data}

Penelitian yang mengkaji unsur bahasa leksikon dalam teknik analisis data biasanya menggunakan metode leksikostatistik, demikian juga halnya dengan penelitian ini. Adapun langkah-langkah dalam menganalisis data penelitian ini adalah (a) mengumpulkan leksikon, dan (b) mendeskripsi potensi penyusutan leksikon karena perubahan pola interaksi masyarakat dengan lingkungan.

\section{Pembahasan}

\section{Kaitan Linguistik dan Lingkungan}

Pelestarian lingkungan merupakan permasalahan penting dan menjadi tanggung jawab semua pihak untuk mewujudkannya, tidak terkecuali bagi para pemerhati, akademisi, ilmuan atau praktisi bahasa. Secara konkret kaitan antara bahasa dengan lingkungan dapat dilihat pada pembelajaran bahasa. Dalam praktik 
pembelajaran bahasa pada berbagai jenjang pendidikan, terdapat empat kompetensi yang ditekankan untuk dikuasai peserta belajar. Keempat kompetensi tersebut adalah menyimak, berbicara, membaca, dan menulis.

Pengajaran keempat kompetensi berbahasa mutlak membutuhkan salah satu produk bahasa berupa tulisan yang berisi upaya-upaya pelestarian lingkungan. Melalui tulisan ini, kompetensi membaca yang bertujuan menggali informasi dari bahan bacaan diajarkan. Melalui tulisan, peserta belajar dapat diajak mengamati bentukbentuk tulisan yang baik dan benar sehingga mereka dapat belajar menghasilkan tulisan yang baik. Melatih keterampilan menyimak pun tidak terlepas dari tulisan, dalam praktik pengajarannya, seorang guru atau pembimbing dapat membacakan suatu tulisan dan meminta peserta belajar untuk menyimak tulisan yang dibacakan guru. Sementara itu, praktik pengajaran berbicara dapat dilakukan dengan meminta peserta belajar menyampaikan secara lisan informasi yang telah didapatkan dari membaca suatu tulisan.

Bentuk lain keterkaitan antara pelestarian lingkungan dengan bahasa tampak pada sifat resiprokal (saling mempengaruhi) antarkeduanya. Pelestarian bentukbentuk bahasa sangat ditentukan oleh lestarinya lingkungan baik alam, sosial, dan budaya. Hasil pengamatan peneliti menunjukkan bahwa terdapat beberapa bentuk bahasa daerah yang berpotensi punah dan tidak dikenal lagi oleh generasi masyarakat penuturnya. Hilangnya produk bahasa ini tidak sekadar tidak dikenal lagi kosakata tertentu, namun budaya yang terkait dengan kosakata tersebut pun menjadi hilang. Dalam hal ini ekosistem suatu lingkungan menjadi tidak dapat dipertahankan.

Berikut digambarkan beberapa kosakata bahasa daerah yang berpotensi punah beserta lingkungan budaya yang menyertainya.

\section{a. Beleseng}

Setelah panen padi dilakukan, orang-orang Sasak di daerah penelitian ini dulu biasanya tidak langsung membawa hasil panennya pulang melainkan dikeringkan di sawahnya. Setelah ukuran keringnya dirasa cukup, pemilik sawah kemudian mengikat padinya menjadi beberapa ikatan. Satu ikat diistilahkan dengan stekel dalam bahasa Sasak daerah penelitian. Proses mengikat padi ini sama dengan proses packing dalam perusahaan sehingga hasil panen siap dibawa pulang.

Ada nilai kearifan lokal yang terkandung dalam proses pengepakan ini yaitu nilai kebersamaan, gotong royong, silaturahmi, dan saling membantu antara pemilik sawah dengan masyarakat yang lain. Masyarakat sekitar datang secara sukarela mambantu proses pengepakan. Setelah proses pengepakan selesai, hasil panen ini kemudian dibawa pulang dengan cara diupahkan yang dalam istilah daerah penelitian disebut dengan beleseng. Artinya, masyarakat sekitar yang berpartisipasi membawakan hasil panen pemiliki sawah akan diberikan upah sesuai dengan kemampuannya membawa jumlah ikatan padi. 
Tradisi beleseng ini di daerah penelitian sudah tidak lagi ditemukan sebab proses pengepakan dalam bentuk ikatan-ikatan (setekel) ini tidak lagi dilestarikan. Entah karena jenis padi yang ditanam petani sekarang dengan dulu berbeda ataupun karena lebih memilih model pengepakan yang lebih praktis misalnya langsung dimasukkan dalam karung sehingga lebih mudah dalam penyimpanan. Padahal dalam tradisi beleseng ini ada nilai karakter yang diajarkan terutama pada anak-anak yaitu kekuatan, kemandirian, dan kesabaran. Pelajaran menghargai jerih payah sendiri pun terkandung dalam tradisi ini. Hilangnya tradisi beleseng ini tidak hanya menghilangkan kesempatan transfer nilai pada anak-anak, tetapi hilang pula unsurunsur bahasa yang terkait.

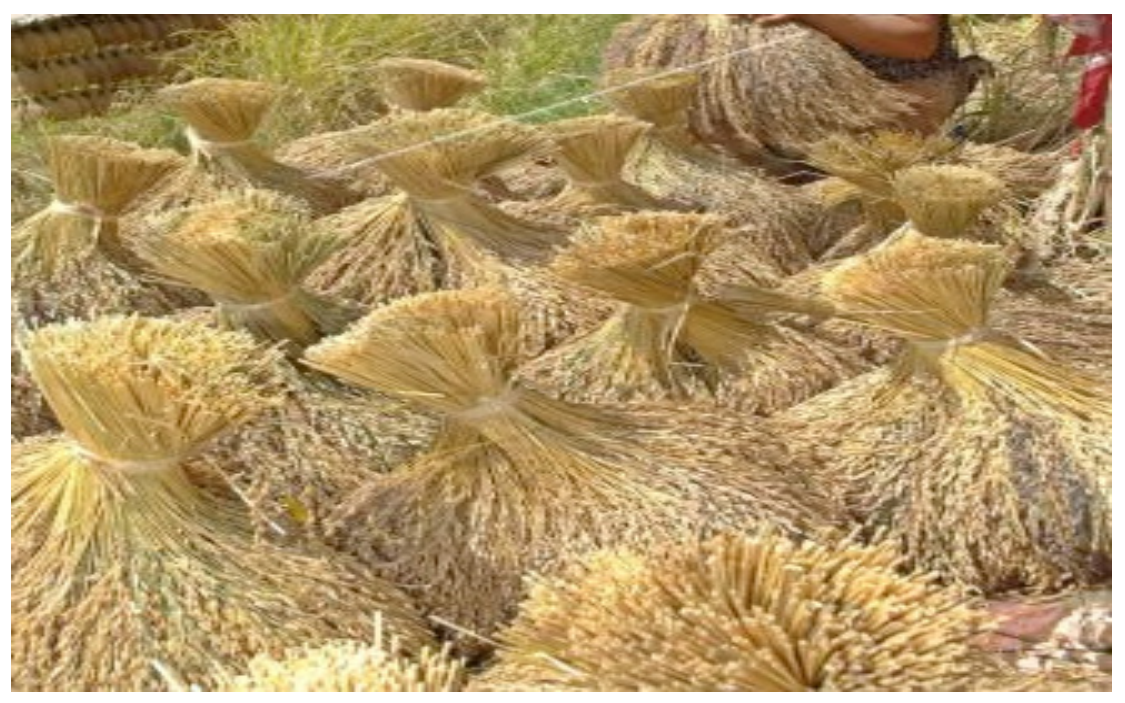

Gambar 1. Setekel "ikatan padi setelah panen"

Nilai-nilai ini tidak lagi ditemukan sebab proses panen padi, pengepakan, hingga pengangkutan ke rumah pemiliki sawah sudah berganti model yang lebih banyak dengan sentuhan mesin. Dalam hal ini, ada budaya yang hilang, ada kearifan lokal yang tidak lagi dipertahankan diringi dengan potensi punahnya satu unsur bahasa daerah.

\section{b. Nenggale}

Aktivitas membajak sawah dalam daerah penelitian disebut nenggale tentu merupakan hal yang sangat akrab dengan kehidupan para petani. Aktivitas ini pada awalnya dilakukan dengan menggunakan sepasang sapi yang digunakan untuk menarik alat pembajak sawah tradisional yang disebut tenggale. Alat ini terdiri atas tiga bagian yaitu gau, ponggoan, dan sampi. Gau adalah alat bajak dari kayu yang dibuatkan digunakan untuk memecah atau menghancurkan bongkahan tanah sawah yang dibajak, ponggoan dipasang di atas punuk sapi dan mengait ke gau. Sedangkan sapi berfungsi untuk menarik kedua alat tersebut sehingga bisa berfungsi. 


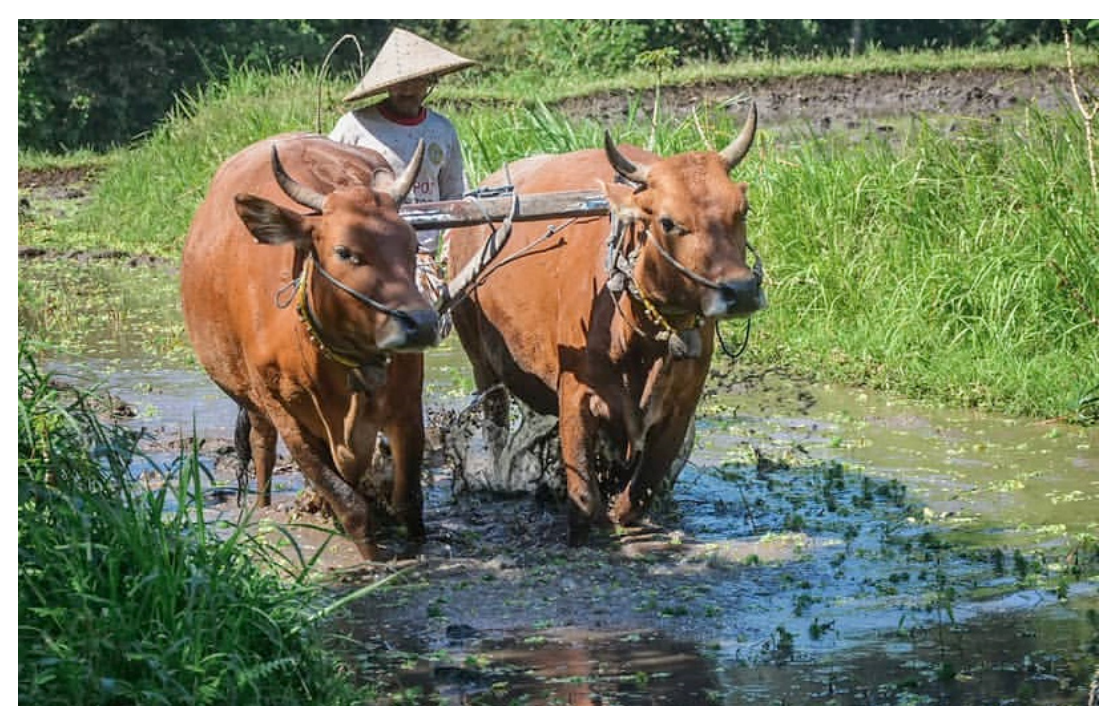

Gambar 2. tenggale "alat pembajak sawah tradisional”

Alat pembajak sawah taradisional ini tidak lagi familiar di kalangan generasi muda karena sudah bergeser ke alat yang modern yang disebut traktor. Beberapa unsur kebahasaan ini berpotensi punah seiring dengan jarangnya penggunaan alat tradisional ini.

\section{c. Berompok}

Penjelasan di atas telah menyinggung bahwa masyarakat di daerah penelitian ini telah mengalami banyak pola interaksi dengan lingkungan terutama dalam mengelola masalah pertanian. Selain peralatan membajak sawah yang kini telah bergeser pada peralatan bermesin, alat panen pada masyarakat pun tidak ketinggalan. Masyarakat pada daerah penelitian yang penulis amati dulu mengenal istilah berompok, dalam bahasa Sasak dialek lain disebut ngerampek. Filosofi pemakaian istilah berompok ini karena padi yang dipanen itu dipukulkan pada alat penennya yang disebut perompok. Saat ini alat panen padi di daerah penelitian ini tidak lagi banyak ditemukan karena telah bergeser menggunakan mesin.

Beralihnya masyarakat yang menggunakan alat panen padi tradisional ini berimplikasi pada berkurangnya tenaga kerja yang diserap. Hal ini berarti bahwa kesempatan masyarakat lain untuk mendapatkan pekerjaan guna menghidupi anak dan keluarganya menjadi semakin sempit. Selain itu, istilah perompok berpotensi tidak lagi dikenal oleh generasi muda sebab mereka tidak lagi menemukan alat tersebut karena tidak digunakan para petani. Sebagaimana terjadi pada unsur bahasa yang telah dijelaskan di atas, hilangnya suatu budanya berpengaruh pada eksistensi unsur bahasa yang terkait dengannya. Hal ini akan terjadi pula pada istilah perompok. 


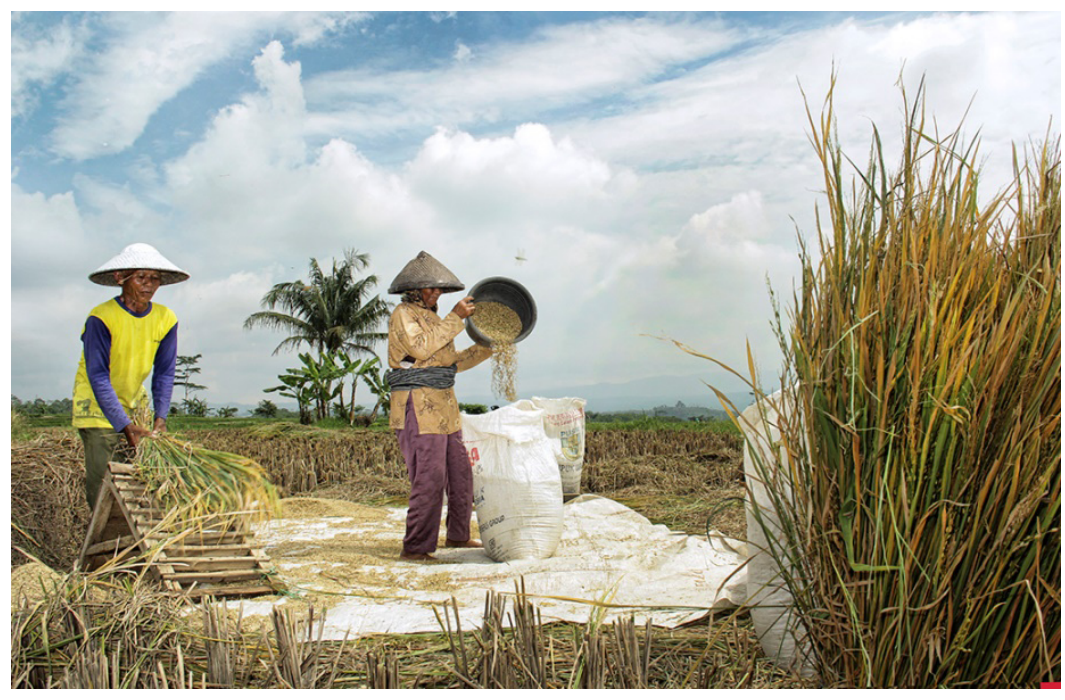

Gambar 3. Berompok "panen padi dengan alat tradisional"

Uraian di atas menjelaskan bahwa masyarakat kita memiliki tradisi dalam berbagai bidang yang berperan penting dalam pelestarian unsur-unsur bahasa. Namun demikian, pola interaksi masyarakat dengan lingkungan baik lingkungan sosial, budaya, maupun alam telah mengalami pergeseran sebagai akibat dari perkembangan zaman. Tradisi lama yang telah berurat berakar dalam masyarakat mengalami pergeseran dan penggantian dengan budaya-budaya baru. Perubahan tersebut tentu membawa dampak yaitu tidak lagi digunakannya beberapa unsur bahasa yang terkait dengan tradisi yang ada. Hal ini tentu sangat disayangkan sebab tradisi masyarakat pada waktu dulu menjadi modal sosial yang patut dilestarikan.

Dalam konteks lingkungan sosial, Saharudin menjelaskan bahwa modal sosial (social capital) yang dimiliki masyarakat pada mulanya sangat efektif digunakan sebagai media penyelesaian berbagai persoalan sosial sehari-hari. Selain itu, modal sosial ini juga digunakan sebagai sarana membangun rasa persaudaraan, solidaritas, hingga harmonisasi sosial. ${ }^{11}$ Selain masalah mulai lunturnya modal sosial yang ada dalam masyarakat, fenomena lain sudah tampak adalah eksistensi bahasa daerah setempat. Bahasa sebagai salah satu unsur dalam kebudayaan bersifat dinamis sehingga rentan mengalami pergeseran akibat pengaruh dari luar komunitas/suku penutur bahasa tersebut.

Pergeseran bahasa yang terjadi dalam masyarakat dapat berupa munculnya bentuk-bentuk bahasa yang baru dan menggantikan bentuk-bentuk bahasa bahasa yang lama. Pergeseran tersebut disebabkan faktor internal dan eksternal. Faktor intenal penyebab pergeseran unsur kebahasaan tersebut di antaranya adalah tuntutan kebutuhan manusia itu sendiri yakni kebutuhan masyarakat yang semakin kompleks. Sedangkan faktor eksternal dapat berupa pemerintah atau negara. ${ }^{12}$

11 Saharudin(2014). Refleksi kohesivitas sosial penutur bahasa sasak dan kecenderungannya bertransformasi. Makara Hubs-Asia, 18(2): 140-148. DOI: 10.7454/mssh.v18i2.3468

12 Ibid. 
Berdasarkan hasil penelitian yang telah dilakukan dapat disimpulkan bahwa eksistensi bahasa sangat erat kaitannya dengan pola interaksi masyarakat dengan lingkungannya. Berkaitan dengan hal ini, Saharudin menyebutkan ada beberapa faktor yang menyebabkan terjadinya pergeseran verbal pada masyarakat Sasak yang berimplikasi pada pergeseran sistem sosial masyarakat penuturnya. Faktor tersebut yaitu: (1) adanya tuntutan kualifikasi baru, (2) bergesernya peran profesi, (3) munculnya stratifikasi kompleks dalam masyarakat, (4) perkembangan institusi pemerintahan.

\section{Kaitan Fiqh Al-Bi'ah dan Pelestarian Lingkungan}

Masalah lingkungan merupakan masalah global sehingga meuntut semua pihak untuk berperan aktif dalam upaya pelestariannya. Kajian-kajian yang mendalam terhadap urgensi pelestarian lingkungan pun layak dilakukan berdasarkan perspektif bidang ilmu yang beragam. Uraian pada subbab di atas telah menggambarkan kaitan antara pelestarian lingkungan dengan eksistensi unsur kebahasaan. Pada subbab ini akan diuraikan kaitan antara lingkungan dengan fiqh al-bi'ah sebagai bagian dari fikih kontemporer. Sebagaimana telah disinggung bahwa fiqh al-bi'ah dimaksudkan untuk menyikapi permasalahan lingkungan dari sudut pandang yang lebih praktis. Kajian fiqh al-bi'ah akan memberikan patokan-patokan (hukum) dalam berinteraksi, mengelola dan memelihara lingkungan.

Praktik pelestarian lingkungan dalam Islam pada dasarnya dapat ditelusuri pada diri Nabi Muhammad saw, para sahabat dan manhaj fiqh kalangan salaf. Sebagai contoh, Nabi Muhammad pernah mengajarkan contoh memelihara alam melalui pencanangan konsep hima. Konsep hima yakni lahan konservasi yang dalam konteks sekarang lahan tersebut sepadan dengan istilah taman kota, kawasan terbuka hijau, suaka marga satwa dan sejenisnya. Selain itu, konservasi lingkungan yang diajarkan Rasulullah Saw terkandung dalam ritual haji. Sebagaimana diketahui, bahwa setiap orang yang datang mengunjungi baitullah ke tanah haram (Mekkah-Madinah) untuk berhaji harus berhati-hati terhadap berbagai tanaman/tumbuhan dan hewan. Dalam praktiknya, jamaah haji yang mencabut tanaman akan didenda seekor kambing. ${ }^{13}$ Praktik pelestarian lingkungan yang diajarkan Nabi Muhammad Saw tersebut mengandung pesan bahwa setiap orang selayaknya memiliki kepedulian dan sensitivitas terhadap pelestarian lingkungan. Demikianlah Islam dengan hukumhukum fiqihnya mengatur pola interaksi masusia dengan lingkungannya.

Selain itu, Alquran sebagai sumber hukum tertinggi dalam Islam telah memberikan panduan kepada manusia untuk bersikap ramah terhadap bumi demi menjaga keberlangsungan hidup manusia itu sendiri. Perintah menjaga pelestarian lingkungan ini tergambar jelas dalam Alquran surat Al A’raf ayat 56.

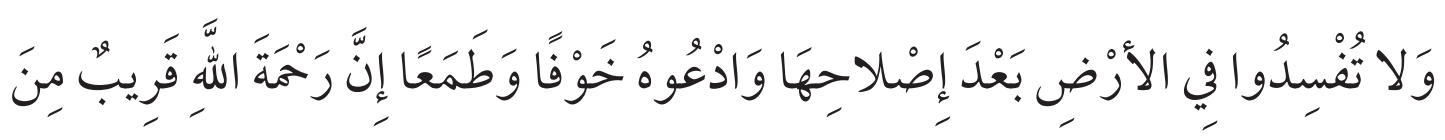

13 Hasan Ubaidillah (2010). "Fiqh al-Biah (Formulasi Konsep al-Maqasid al-Shari'ah dalam Konservasi dan Restorasi Lingkungan)”. Al-Qanun, 13 (1): 26-52. 


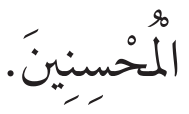

Dan janganlah kamu membuat kerusakan di muka bumi, sesudah (Allah) memperbaikinya dan berdoalah kepada-Nya dengan rasa takut (tidak akan diterima) dan harapan (akan dikabulkan). Sesungguhnya rahmat Allah amat dekat kepada orang-orang yang berbuat baik.

Perintah menjaga kelestarian ini terkait dengan beragam kerusakan yang terjadi sebab perilaku dan pola interaksi manusia dengan lingkungannya yang terkadang tidak terkendali. Hal ini tentu disayangkan karena semua kerusakan tersebut tentu berakibat fatal bagi manusia. Gambaran kerusakan yang terjadi ini disebutkan dalam ayat lain dalam Alquran yaitu surat Ar-Rum ayat 41 .

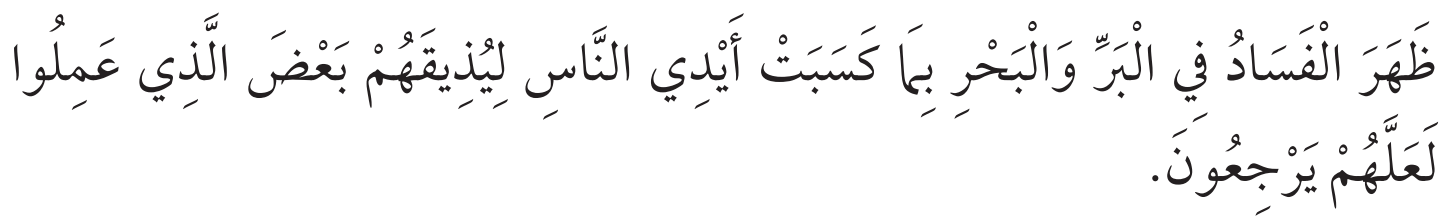

Telah nampak kerusakan di darat dan di laut disebabkan karena perbuatan tangan manusia, supaya Allah merasakan kepada mereka sebahagian dari (akibat) perbuatan mereka, agar mereka kembali (ke jalan yang benar).

Perintah Allah SWT melalui berbagai ayat Al-Quran dan ajaran Rasulullah saw melalui praktik pelestarian lingkungan tersebut memberikan pelajaran kepada kita semua agar manusia selalu menjaga dan melestarikan alam dan lingkungan agar tidak terjadi kerusakan, ketercemaran bahkan kepunahan. Berdasarkan tuntunan ini kita dapat mengambil kesimpulan bahwa upaya-upaya pelestarian lingkungan sangat ditekankan dalam Islam melalui hukum-hukum fiqihnya. Salah satunya adalah fiqh albi'ah. Dengan demikian, fiqh al-bi'ah dapat diposisikan sebagai salah satu subdisiplin ilmu dalam kerangka fiqh secara global.

Perumusan fikih lingkungan menjadi penting dalam upaya memberikan wawasan dan pandangan baru untuk melakukan pengelolaan lingkungan melalui ajaran agama yang sesuai dengan hukum syara. Bahkan rumusan figh al-bi'ah ini dapat pula memuat sanksi bagi pelanggar atau perusak lingkungan. Rumusan ini menjadi penting karena dapat menjadi pedoman dalam mengatur hubungan manusia dengan Tuhannya, dengan dirinya sendiri, dengan sesama manusia, dan dengan lingkungan hidup di sekitarnya. Perumusan dan pengembangan fiqh lingkungan (fiqh al-bi'ah) menjadi suatu pilihan urgen di tengah krisis ekologis oleh keserakahan manusia dan kecerobohan penggunaan teknologi. ${ }^{14}$ 


\section{Konvergensi antara Ekolinguistik dan Fiqh al-Bi'ah dalam Pelestarian Lingkungan}

Kaitan antara linguistik dengan lingkungan telah dikupas pada subbab A di atas sedangkan pada subbab B mengulas tentang pandangan fiqh tentang pelestarian lingkungan. Kedua subbab di atas menyimpulkan bahwa pelestarian lingkungan menjadi bagian penting dalam kehidupan manusia karena dapat menjadi sarana menjaga eksistensi unsur bahasa maupun keberlangsungan hidup manusia. Dengan demikian, dapat dikatakan bahwa titik temu (konvergensi) antara ekolingusitik dan fiqh al-bi'ah dalam pelestarian lingkungan ini adalah memposisikan pelestarian sebagai aktivitas penting dalam menjaga eksistensi keduanya.

Konvergensi antara ekolinguistik dan fiqh al-bi'ah dalam pelestarian lingkungan baik lingkungan sosial, budaya, maupun alam yang melihat masalah pelestarian lingkungan sebagai masalah bersama disebabkan beberapa hal:

1. Adanya gejala yang kuat terhadap ketercerabutan nilai-nilai kearifan lokal (local wisdom) di kalangan generasi muda karena pudarnya fungsi bahasa dan budaya daerah seiring dengan berkembangnya pola kehidupan masyarakat. Dalam perspektif ekolinguistik, hal ini mengakibatkan punah atau hilangnya unsurunsur bahasa yang selama ini menjadi identitas masyarakat penuturnya. Dalam perspektif fiqh, persoalan ini tidak dapat dilepaskan dari tujuan utama ilmu fiqh yang mengatur hubungan manusia dengan Allah SWT, hubungan dengan sesama baik dalam bentuk hubungan kekeluargaan maupun dalam bentuk hubungan kebendaan.

2. Adanya gejala ketidakserasian hubungan manusia dengan lingkungan baik lingkungan alam maupun lingkungan sosial yang saling memengaruhi. Ekolinguistik memandang hal ini sebagai tindakan yang secara tidak sadar menyebabkan lunturnya ekspresi linguistik. Ekspresi linguistik yang luntur ini dibarengi dengan tidak lagi ditemukannya berbagai media, benda, alat dan berbagai jenis kearifan lokal lainnya. Ketidakserasian hubungan manusia dengan lingkungan juga menyebabkan kerusakan dalam berbagai bidang. Dalam hal ini, fiqh al-bi'ah hadir menjadi solusi bagaimana menjaga pola hubungan manusia dengan lingkungannya.

3. Keterancaman hidup bahasa-bahasa daerah yang mengandung nilai-nilai kearifan lokal karena pengaruh dominasi budaya dan bahasa asing. Salah satu karakteristik bahasa adalah dinamis dan selalu berubah seiring dengan perubahan budaya yang ada di tengah masyarakat penuturnya. Sementara itu, perubahan budaya masyarakat tidak dapat dinafikan. Dalam hal ini, alangkah bijaknya suatu masyarakat yang mengalami perubahan tanpa harus larut dan menghilangkan berbagai identitas lokal yang ada termasuk bahasa daerah. Demikianlah ekolinguistik memandang bahwa perlu dilakukan upaya-upaya pemertahanan bahasa daerah dengan pendekatan lingkungan. Fiqh sebagai bagian dari ajaran Islam pun memiliki perspektif bahwa pelestarian bahasa daerah sebagai bagian 
dari nasionalisme harus dimiliki setiap orang. Dengan demikian, baik ekolinguistik maupun figh al-bi'ah memandang pelestarian bahasa daerah adalah persoalan bersama.

Berdasarkan beberapa hal diatas, baik ekolinguistik maupun fiqhal-bi'ah memiliki tujuan bersama sebagai titik temu yaitu memposisikan pelestarian lingkungan sebagai tujuan mencapai kehidupan yang harmonis antara kebertahanan unsurunsur bahasa, budaya, dan lingkungan. Artinya sesuatu yang ingin dituju adalah menjaga eksistensi unsur bahasa berupa ekspresi linguistik dan keberlangsungan kehidupan semua makhluk Tuhan. Hal ini menggambarkan peran ekolinguistik dan figh al-bi'ah sebagai panduan mengatur manusia dan alam sehingga akan memberikan manfaat maksimal bagi kehidupan bersama.

Pemahaman masalah lingkungan hidup dan penanganannya (penyelamatan dan pelestariannya) dari perspektif linguistik dan figh al-bi'ah perlu diposisikan sebagai pondasi moral untuk mendukung segala upaya yang sudah dilakukan yang selama ini belum mampu mengatasi potensi pergeseran dan kepunahan bahasa serta kerusakan lingkungan hidup yang sudah ada dan masih terus berlangsung. Kedua kajian ini (ekolinguistik dan figh al-bi'ah) berupaya memberikan pemahaman supaya masyarakat menyadari bahwa permasalahan lingkungan hidup tidak dapat dilepaskan dari tanggung jawabnya. Selain itu, permasalahan lingkungan hidup merupakan amanat yang diemban untuk merawat dan menjaga lingkungan sebagai hunian tempat manusia dalam menjalani kehidupan..

\section{E. Penutup}

Islam sebagai agama rahmat lil al-'alamîn telah mengatur adab berinteraksi terhadap lingkungan baik lingkungan sosial maupun alam. Islam dengan jelas menganjurkan manusia untuk menjaga dan memelihara kelestarian lingkungan untuk mencegah terjadinya musibah yang diakibatkan dari perusakan lingkungan. Pola interaksi manusia yang tidak mengedepankan adab dalam pengelolaan lingkungan menyebabkan hilangnya keseimbangan ekosistem yang ada. Hal ini berdampak pula pada menyusutnya beragam budaya dan bahasa lokal yang kaya akan nilai-nilai kearifan. Dalam hal ini terlihat jelas kontribusi fiqh al-bi'ah dalam pengembangan ekolinguistik, khususnya pelestarian budaya dan bahasa lokal. Konsepsi maqashid assyari'ah mengajarkan bahwa pemeliharaan alam sama dengan penjagaan terhadap aspek yang terkait dengan al-usul al-khamsah di dalam materi usul alfigh yakni hifz addin (pemeliharaan agama), hifz an-nafs (pemeliharan jiwa), hifz al-'aql (pemeliharaan akal), hifz al-mal (pemeliharaan harta), dan hifz al-'ardl (pemeliharaan kehormatan).

Ditilik dari perspektif ekolinguistik, dapat disimpulkan bahwa pertama, adanya gejala yang kuat terhadap ketercerabutan nilai-nilai kearifan lokal (local wisdom) di kalangan generasi muda karena mengikisnya fungsi bahasa dan budaya daerah seiring dengan berkembangnya pola kehidupan masyarakat. Kedua, adanya gejala ketidakharmonisan hubungan manusia dengan lingkungan yang saling memengaruhi. Ketiga, keterancaman hidup bahasa-bahasa daerah yang mengandung nilai-nilai 
kearifan lokal karena pengaruh dominasi budaya dan bahasa asing. Keempat hilangnya kegiatan-kegiatan sosial, budaya, dan pertanian menyebabkan hilangnya beragam bentuk bahasa. Beberapa rumusan ini dapatlah dirangkum bahwa lingkungan, memiliki pengaruh besar terhadap kelangsungan dan kebertahanan bahasa yang mengandung nilai-nilai kearifan lokal yang patut dilestarikan. Rumusan ini menegaskan bahwa konsepsi fiqh al bi'ah dan ekolinguistik memiliki satu konvergensi sebagai upaya pelestarian lingkungan.

\section{Daftar Pustaka}

Al-Qardhawi, Y. (2001). Ri'ayatu Al-Bi'ah fi As-Syari'ah Al-Islamiyah. Kairo: Dar AlSyuruq.

Antonius Nesi; R. Kunjana Rahardi; Pranowo. (2019). Nilai-Nilai Kearifan Lokal dalam Tradisi Lisan Takanab: Kajian Ekolinguistik. Jurnal Pendidikan dan Kebudayaan Missio, 71-90.

Busriyanti. (2016). Islam dan Lingkungan Hidup Studi terhadap Fiqh al-Bi'ah sebagai Solusi Pelestarian Ekosistem dalam Perspektif Maqashid al-Syari'ah. Jurnal Fenomena IAIN Jember, 259-280.

Chaer, A. (2003). Psikolingistik Kajian Teoritik. Jakarta: PT Rineka Cipta.

Keraf, A. S. (2010). Etika Lingkungan Hidup. Jakarta: PT Kompas Media Nusantara.

Mardiati, B. T. (2016). Penyusutan Leksikon Bidang Ekonomi pada Masyarakat Tutur Bahasa Sasak dan Implikasinya terhadap Pembelajaran Bahasa Indonesia Tingkat SD di Desa Barabali Kecamatan Batu Kliang. Mataram: Tesis Universitas Mataram.

Mbete, A. M. (2013). "Pembelajaran Bahasa Berbasis Lingkungan:Perspektif Ekolinguistik" (Makalah Bahan Kuliah Umum bagi Karyasiswa Program Magister Pendidikan Bahasa Indonesia Program Pascasarjana Universitas Mataram. Mataram: Tidak Diterbitkan.

Noor, F. (2018). Pengelolaan Sumber Daya Alam Berdasar Prinsip Fiqh Al-Bi'ah. Jurnal Ilmiah Pendidikan Pancasila dan Kewarganegaraan, 47-55.

Santoso, W. J. (2017). Analisis Sosio-Ekono-Ekolinguistik terhadap Pemertahanan Leksikon Tanaman Tradisonal untuk Bumbu Masak bagi Mahasiswi di Kota Semarang. Jurnal Pendidikan Bahasa dan Sastra Indonesia, 69-79.

Subianto, A. (tt). Ekolinguistik: Model Analisis dan Penerapannya. Semarang: Fakultas Ilmu Budaya Universitas Diponegoro.

Thohari, A. (2013). Epistemologi Fikih Lingkungan:Revitalisasi Konsep Masalahah. Az Zarqa': Jurnal Hukum Bisnis Islam, 145-161.

Verhaar, J. (2006). Asas-Asas Lingusitik Umum. Yogyakarta: Gajah Mada University Press. 
El-Tsaqafah: Jurnal Jurusan PBA, Vol. 19, No.2, 2020

W. Citra Juwita Sari; Yohanes Kristianto. (2015). Bahasa dan Ekologi: Sebuah Perspektif Ekolinguistik Dalam Pariwisata. Bali: Universitas Udayana.

Zuhdi, M. H. (2015). Fiqh Al-Bî’ah: Tawaran Hukum Islam Dalam Mengatasi Krisis Ekologi. Al-Adalah, 771-784. 